Dandara Oliveira de Paula ${ }^{1}$

'Universidade Federal do Rio de Janeiro, Rio de Janeiro, RJ, Brasil

\title{
Human Rights and Violence Against Women: Campo Algodonero Case
}

\begin{abstract}
The present article seeks to analyze human rights from a gender perspective. To do so, it goes back to the past to explain the development of the society of rights and women's rights. The analysis starts from the premise that human rights are social products and therefore will reflect and represent the values and interests of the society that produced them, in this case, capitalist society. One of the values of this society is patriarchy and the idea of the superiority of men as a social actor in relation to women. This value is represented in human rights that nevertheless have universality as one of its characteristics: the idea that all people are subjects of such rights independently of any identities. Therefore, the legal text in which human rights were coined affirms an equality that does not exist in practice, since women are violated and their rights are violated every day, in addition to the gender inequality present throughout the world. As an example and materialization of this reality, the Campo Algodonero Case, introduced to the InterAmerican Court of Human Rights, appears as the first case of the Court to mention femicide, showing the vulnerability of women's life and integrity.

Keywords: Human Rights; Women's Human Rights; Latin America; Femicide
\end{abstract}

The period after the Second World War represented a glitch on the normative right's system, especially the international which concerns people's protection, entitled Human Rights. The atrocities that happened in both World Wars, but mainly in the second one, in terms of number of deaths and killing methods, became a milestone of this moment of change in the human rights' protection system.

Looking back, we can mention the declarations born within the scope of the Revolutions of the Bourgeoisie as what led up to Human Rights, and are therefore the predecessors of the rights' historical process. They are the "Bill of Rights" of 1689, the "Declaration of Rights of Man and Citizen" of 1789 and the United States' Constitution during the Independence War (ELÍDIO MARQUES, 2012, p. 1). All of them, emerging when the bourgeoisie ascended to a dominant

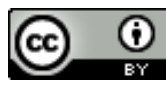

Esta obra está sob licença Creative Commons. 
position as a class, were not a coincidence but a necessity. For when a class rises to power, it needs legal mechanisms that combine its virtues and objectives.

A right is not, consequently, a neutral technique that works by itself. Nor is it the only instrument or way that can be used to legitimize or transform social relations of dominance. Human rights' "right" is, thus, a way - a technique - amongst many others, for ensuring the results of social struggles and its interests, and, as such, cannot step away from the ideologies and expectations of those who control it, both in national and international contexts (Joaquin HERRERA FLORES, 2009). ${ }^{1}$

It was fundamental for the bourgeoisie of the 18th century that all men were equal in the eyes of the law, being they rich or poor, just as much as the protection of private property was of extreme importance; and this thought was present in all rights appearing at that time. Not only was the existence of these laws fundamental, but the government had necessarily to be trusted with their maintenance and fulfillment. The notion of rights was not the sole label called to by the ascending bourgeoisie, there was also the concept of national identity. It was a way of supporting, together with the political power, the modern world.

It must be highlighted, though, that the rights equality shown in this historical context was restricted to the white men, for even though in numerical minority in society, they were and should be seen as the majority under the law and the political power, since rights are products of social struggle and will represent the dominant class (HERRERA FLORES, 2009, p. 18). As the bourgeois needed this cultural and political framework, the white men also needed to remain as the dominant class. The difference now would be that the bourgeois men are society's main actors, ruling the social system, instead of the men of the nobility. The patriarchal logic remains the same, because they were the only subjects of the law, and therefore affected by these legal and political changes. This shows us that the search for rights, at the time, was targeted to one specific sector of society and not for the search for rights for all people. The Declaration of the Rights of Men and of the Citizen considered the bourgeois men, and not all the people, as citizens. This idea coexisted for years with slavery and the exclusion of a large part of the population from access of rights.

However, it is only after the Second World War that Human Rights were born in the sense of rights that would go beyond the States and that they would be willing to respect, rights that should be universal, rights in which "all" represent all of the people regardless of gender, ethnicity and social class, and beyond the logic of nationality, encompassing the entire world. There emerges the idea that they are rights that are inherent in sovereignty, that exist for every individual regardless of where they are and who they are. All of this happened with the creation of the United Nations and its Nation System.

The San Francisco Charter was the constitutive document of the United Nations (UN) and is about the organization's fundamental themes, even though it did not show a more detailed exposition about Human Rights, what was left for the subsequent documents (MARQUES, 2012, p. 8). But this should not reduce the initial landmark that it represented to the human rights protection system, and of course, to international relations.

The Declaration's main idea is presented in its first article: "All human beings are born free and equal in dignity and rights" (UNIVERSAL DECLARATION OF HUMAN RIGHTS, 1948, Art

\footnotetext{
' O direito não é, consequentemente, uma técnica neutra que funciona por si mesma. Tampouco é o único instrumento ou meio que pode ser utilizado para a legitimação ou transformação das relações sociais dominantes. O "direito" dos direitos humanos é, portanto, um meio - uma técnica - entre muitos outros, na hora de garantir o resultado das lutas e interesses sociais e, como tal, não pode se afastar das ideologias e das expectativas dos que controlam seu funcionamento tanto no âmbito nacional como no âmbito internacional (HERRERA FLORES, 2009 [Author's translation]).
}

2 Revista Estudos Feministas, Florianópolis, 26(3): e58582 
1). This article acknowledges that every human being is born free and equal, in other words, that human rights are inside the logic of natural rights, that they are inherent to every human being, regardless of their nationality, wealth, religion and any other factor. And, therefore, are universal. The Declaration of 1948 was a landmark. It is a document that supports the international order of cooperation and the supremacy of international institutions. It was one of the first documents that compelled the States to take actions that reduced their autonomy in the post-war national and international contexts.

Only in 1979 people started to think and specify Human Rights from the point of view of the violations suffered by women with the 'Convention on the Elimination of All Forms of Discrimination against Women' (1979). However, it was enforced only in 1981, being the first international document oriented exclusively to women's rights and the combat of all forms of discrimination that this minority suffers. It has two main objectives. The first one is to promote women's rights, seeking gender equality. And the second one is to fight against any type of discrimination suffered by women in the countries that are members of the Convention.

The Convention starts a global wave in the promotion of human rights, especially those of minorities. It brings to light all the physical and psychological assaults that women suffered throughout centuries. And, mainly, it is an instrument to achieve gender equality, since it is claimed in the UN Declaration of Human Rights that men and women are equal. Nevertheless, this equality is far from being effective. The 'Convention on the Elimination of All Forms of Discrimination against Women', together with earlier conventions, such as the 'Convention on Political Rights of Women' adopted in 1952 (1953) and the 'Convention on Nationality of Married Women' adopted in 1957 (1958), among others, came in order to achieve this equality in a faster, fairer and more effective way.

The Convention demands that the States adapt so that women's human rights can be brought to light in their internal legal systems. Nevertheless, this demand is not that efficient, because it depends on the States' will, and on their desire to respect the Convention's rules. In the international system we live in, the States have legal autonomy and that can hamper not only the effectiveness, but also the validation of human rights. Thus, the Convention and all the rights that it brings need to be approved by the Legislative and Judiciary Branches of all countries so they can have total effect.

On the promotion of women's human rights and the fight for gender equality, we have another important institutionalized instrument: The UN Women. Founded in 2010 by the UN General Assembly, it symbolizes a historical landmark to speed up the implementation of gender equality and empowerment goals.

In 1995, the Fourth World Conference on Women, in Beijing, established a Declaration and Platform for Action, which fought against gender discrimination and aimed at achieving greater equality and opportunities for women worldwide. The conference undertook an analysis of the advances that came with previous meetings (Nairobi, 1985; Copenhagen, 1980 and México City, 1975) and of the obstacles that still stood in the way of gender equality. The Declaration is considered a model for achieving already established goals, because more than recommendations, it proposes specific actions to be taken.

Twelve main areas of action were identified to be taken by the Declaration's signing states, each one with its specific plan set in the Declaration, being this the main difference from the ones that came before. Despite that, very little progress is being seen by the States in all the priority areas. We can understand that, even though the areas are divided in separate themes, they are all interconnected in actions, as society works in an interconnected way. Removing women from poverty is directly connected with women's human rights policies, for example. As little progress was seen in each area, little progress was achieved as a whole. 


\section{Human Rights in Latin America}

Latin America fits perfectly in the situation outlined above about women and human rights. It is a place where historically women are widely discriminated and violated in all forms possible, and where patriarchy has more force than in the Northern hemisphere, subordinating Latin women to a wide range of oppression today if we compare to women living in the so called developed countries.

The Organization of American States was a continental organization created in 1948 through the signature of the OAS Charter, in Bogota, and has the purpose of creating bonds among the fellow states "to achieve an order of peace and justice, to promote their solidarity, to strengthen their collaboration, and to defend their sovereignty, their territorial integrity, and their independence" (the Charter of the OAS, Chapter 1, Art 1, 1967).

In the OAS' foundation Charter (1967), the States affirmed some principles which they believed were the pillars for the functioning of the organization. Among them is: "The American States proclaim the fundamental rights of the individual without distinction as to race, nationality, creed, or sex" (OAS Charter, Chapter II, Art 3, 1967). ${ }^{2}$

The OAS foresees a right's monitoring and implementation apparatus, consisting of the Inter-American Commission on Human Rights and the Inter-American Judicial Committee. The Commission's main function is to promote the compliance and the protection of human rights in the American continent. Its actors are not only the States, as in most international organisms, but also NGOs and individuals or groups of individuals. This makes it more accessible than other institutions. Any resident person of one of the Charter signatory countries can present an accusation on the violation of human rights by any State, even the ones that did not sign the Charter. This takes part of the State's power on what is brought to the international institutions, passing the power to the individuals, the most vulnerable level on the logic of international relations. It guarantees individuals the way to forward their own demands, the right to individual petition, rendering the effectiveness of human rights detached from political decisions.

The Inter-American Judicial Committee is an autonomous judicial body. It was created by San José da Costa Rica Pact to apply and interpret the Inter-American Convention on Human Rights and other human rights threats. Together with the Inter-American Commission on Human Rights, it forms the Inter-American System of Human rights Protection.

In terms of Women's Human Rights, an Inter-American Commission on Women was established in 1928, becoming the first inter-governmental body to ensure and acknowledge women's human rights. It has turned into the main debate and formulation forum about women's human rights and gender equality in America.

Women in Latin-America remain at a disadvantage in relation to all economic and social development indicators. With exception of countries with higher incomes, women stand out in literacy and primary education rates. In poor countries, like Bolivia, Guatemala and Haiti, the feminine access to education remains smaller than the male one. Women in Latin-America remain unprotected because of the ineffectiveness of all these programs on Latin-American women, especially the poor ones.

One of the many examples is the gigantic number of women's death by domestic violence and little has changed over the years. Domestic violence is the most common manifestation of gender violence. According to the Mundial Health Organization (MHO) (2005), Brazilian women that are in a relationship have reported that they suffered physical violence at least once, $27 \%$ in São Paulo and 33\% in Pernambuco. Meanwhile 10\% in São Paulo and $14 \%$ in Pernambuco have suffered sexual assault. $12 \%$ of all women in São Paulo and $9 \%$ in

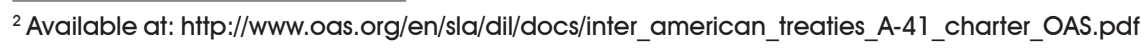


Pernambuco affirm having faced physical or sexual violence before they were 15 years old. The same MHO survey asserted that among Peruvian women that have a male partner, $51 \%$ in Lima and $69 \%$ in Cusco suffered acts of physical and/or sexual violence by their partners. In absolute numbers on gender violence the percentage was $23 \%$ in Lima and $47 \%$ in Cusco.

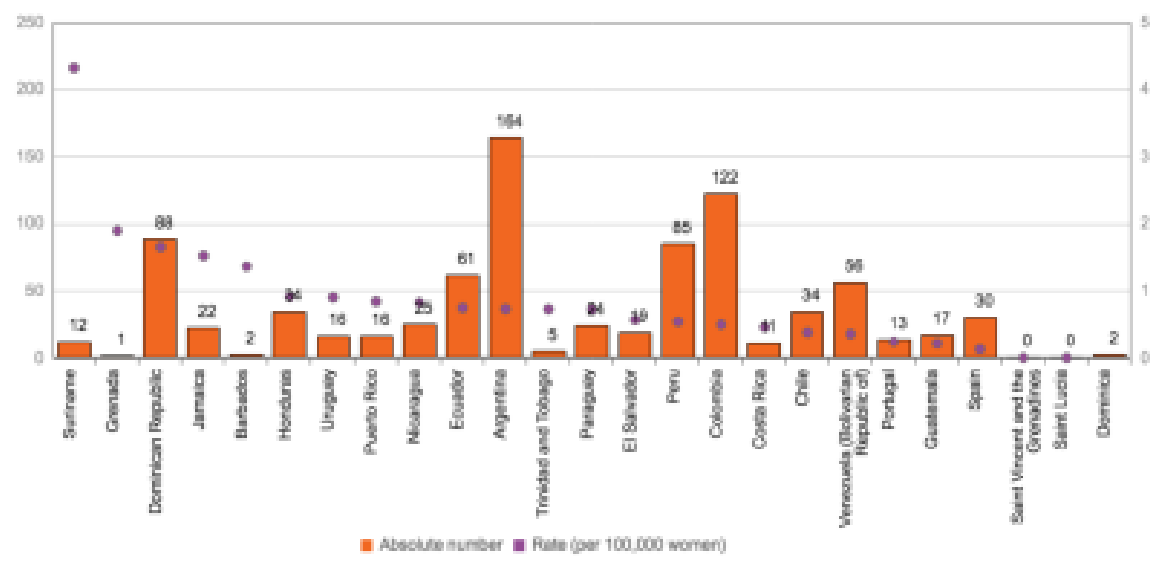

Image I: Women's death at the hand of their intimate partner of former partner ${ }^{3}$

Even though Human Rights exist on the private and public sphere, the violence against women (mainly within the family or domestic violence) is still considered, on a social level, a private problem to be handled by the couple and not an issue of gender security or femicide. This really means in practice that this problem is not included on the public policies' agenda on a national level. Besides, it is not seen as part of the security protection work in most countries of the region. Simultaneously, it is clear that women are excluded from the decision making committees and from forums related to security.

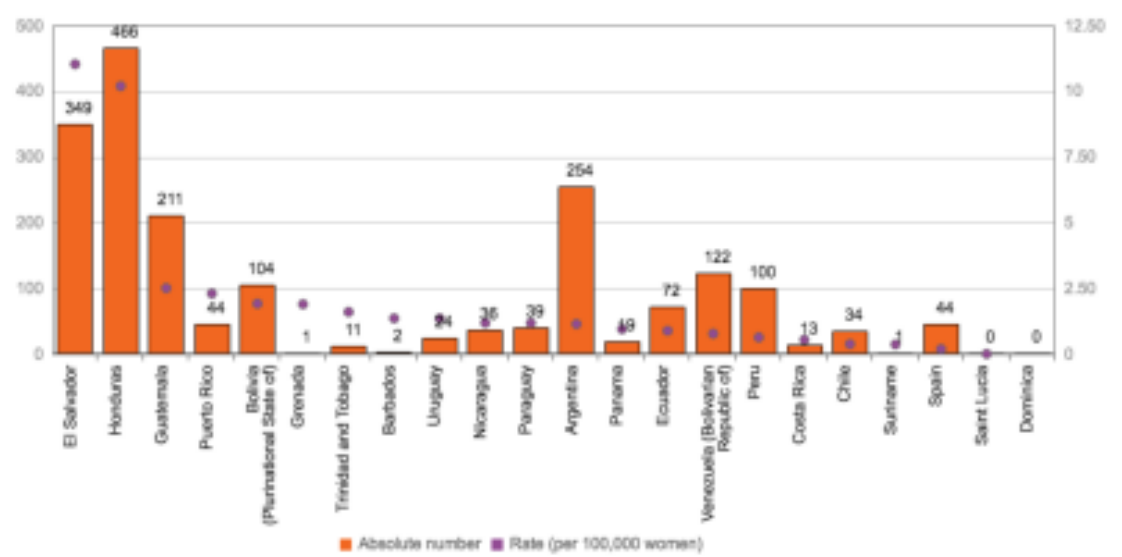

Image 2: Femicide, 2014 (Absolute numbers and a 100.000 women rate) ${ }^{4}$

${ }^{3}$ Available at: http://oig.cepal.org/en/indicators/womens-deaths-hands-their-intimate-partner-or-former-partner ${ }^{4}$ Available at: http://oig.cepal.org/en/indicators/femicide-or-feminicide 
Between the years of 2010 and 2015, the number of Latin-American countries that defined femicide in their legal codes increased from four to sixteen. But the legal reforms must be associated with better tools, as well as campaigns to increase society's awareness on the subject.

\section{The Campo Algodonero Case}

A historical milestone of the feminist fight on violence against women was the Campo Algodonero Case (2009) of the Inter-American Judicial Committee. The case is about the murder of many women in Ciudad Juárez, in Mexico. The disappearance of Claudia Ivette Gonzalez, Esmeralda Herrera Monreal and Laura Berenice Ramos Monárrez was the key fact around which the case was developed. For the first time an international court acknowledged the term femicide as reference to the systematic violation of the women's right to live due to gender. The case connects the femicide issue in Ciudad Juárez to the presence of maquiladoras in this city, located on the border of US and Mexico.

The case (2009) takes place in a Mexican zone dominated by the maquiladoras. Therefore, the State's role as supervisor and guarantor is small. In this area, a large number of people that are employed by these companies live in precarious conditions. These factories prefer to hire women because they accept a lower salary than men, and the main objective of this kind of company is profit. On their commute back home from work many women are assaulted, raped and killed and the State does nothing about it. So, there is the combination of a region with little presence of the State with no interest in women's rights in a capitalist, male-dominated society, what renders these women completely vulnerable. The Campo Algodonero Case (2009) focuses on three specific cases of women murdered and the increase of women's deaths in the area, introducing the term femicide to International Law and to Human Rights.

Among the irregularities are the fact that they did not start the searches immediately after their disappearance and denied giving information to Esmeralda's mother, ordering her to buy newspapers so she could follow the news of the case. Also, they did not notify her when the body of her daughter was found; there was no information about the results of the evidences found; the body had disappeared for only 8 days but the hair and face were gone (the authorities informed that animals and the wind must have destroyed her), but her body was naked and intact; they did not deliver to the relatives any autopsy documents; they did not allow the relatives to be around when the body was taken to the grave; they did not share DNA tests; they tried to convince them that the people responsible for the death were in prison; yet the alleged murderers claimed that their confession was taken under torture. When they returned the body to the family, they shut down the case and the relatives were victims of persecution, maltreatment and intimidation by the authorities.

On March 6th 2002, Irma Monreal, mother of the victim and the Red Ciudadana de No Violencia y por la Dignidad Humana presented an accusation to the Inter-American Judicial Committee (OAS), claiming the State's international responsibility for the violations of the Belém do Pará Convention, to the Inter-American Convention on Human Rights and to the American Declaration. On February 25th, 2005 the IACHR declared the admissibility of the case, through report $N^{\circ} 28 / 07$, and decided to add the cases of 17 -year-old Laura Berenice Ramos Monarrez and 20-year-old Claudia Ivette Gonzales to the case of Esmeralda Herrera Monreal (OAS, 2007 [2005]). All murders had happened in the same city and therefore became known as the "Campo Algodonero Case". The Committee made its decision and gave Mexico two months to report on the measures and to fulfill the recommendations. The country then asked for an 18-month extension, so they could accomplish the recommendations. On

6 Revista Estudos Feministas, Florianópolis, 26(3): e58582 
July 3rd, IACHR informed that they had accepted the Mexican claim, and extended their deadline for four months.

On this date the IACHR lodged to the Committee a demand against Mexico on the cases 12.496, 12.497, 12.498, ("Campo Algodonero: Claudia Ivette Gonzalez, Esmeralda Herrera Moneral e Laura Berenice Ramos Monarrez) (OAS, 2007 [2005]) for denial of justice in relation to the disappearance and murders in Ciudad Juarez; lack of prevention in cases like these, even though the authorities were aware of the gender violence pattern in the city; the lack of authorities responses facing the disappearances; the lack of seriousness in the investigation; the lack of adequate reparation to the victim's family. On December 26th, 2007, the Committee notified the acceptance of the case and in February 2008 presented the demand through the document "Arguments, requests and proofs" (author's translation) formulated by the victims' mothers. In the period from April 27th to April 30th 2009, the Committee met in Santiago, Chile, where an audience on the "Campo Algodonero" case was held to hear the witnesses and the experts.

The Inter-American Judicial Committee, on November 16th, 2009, issued a sentence against the Mexican State pointing out, among other things, that the State did not fulfill its duty to investigate and to ensure the rights to life, personal integrity and personal freedom with irreparable damage to Claudia Ivette González, Laura Berenice Ramos Monárrez and Esmeralda Herrera Monreal (OAS, 2009). For the same reasons the Mexican State violated the right to access to the justice system and its protection, established in articles 8.1 and 25.1 of the Inter-American Charter.

The State violated the right of live, personal integrity and personal freedom acknowledge on the articles 4.1, 5.1, 5.2 and 7.1 of the American Convention, in relation to the general duty to guarantee the article 1.1 and the duty to adopt internal legal provision on the 2 article of the same document, as well as the obligations on the article 7.b and 7.c of Belém do Pará Convention, to the determiner of Claudia Ivette González, Laura Berenice Ramos Monárrez e Esmeralda Herrera Monreal, on the same terms as the paragraphic 243 to 286 of the present sentence. (OEA, Concención Americana, p. 151 [Author's translation] $)^{5}$

The case (2009) became a milestone in Human Rights and Women's Human Rights. Even though the term was not considered in the judgment (the case was judged as serial murders and not as death by gender), it was the first time that "femicide" was used in an international court. These cases crystallized the issues faced by poor women in a patriarchal and capitalist society. Because of commercial deals aiming to raise their income, governments allow companies to explore the workforce and even to ignore human rights and labor rights. This permissiveness combined with the neglect of human rights creates a favorable scenario for this kind of rights violations as the impunity is a reality. In patriarchy, society naturalizes the violations against women's bodies and the blame falls on the victim. Besides, the violence against women is understood as a private matter and, because of that, governments should not intervene, denying the proper assistance to the victim or to her family in any case of gender violence.

${ }^{5}$ El Estado violó los derechos a la vida, integridad personal y libertad personal reconocidos en los artículos 4.1 5.1, 5.2 y 7.1 de la Convención Americana, en relación con la obligación general de garantía contemplada en el artículo 1.1 y la obligación de adoptar disposiciones de derecho interno contemplada en el artículo 2 de la misma, así como con las obligaciones contempladas en el artículo 7.b y 7.c de la Convención Belém do Pará, en perjuicio de Claudia Ivette González, Laura Berenice Ramos Monárrez y Esmeralda Herrera Monreal, en los términos de los párrafos 243 a 286 de la presente Sentencia. (versão original) 


\section{References}

CAMPO ALGODONERO. Condena. http://www.campoalgodonero.org.mx/condena HERRERA FLORES, Joaquin. A Reinvenção dos Direitos Humanos. Florianópolis: Fundação Boiteux, 2009.

MARQUES, Elídio. A emergência dos Direitos Humanos: de "promessas nacionais" à parte fundamental do Direito Internacional. In: Educação em Direitos Humanos e Diversidade ONU. Convenção de Eliminação de Todas as Formas de Discriminação Contra a Mulher, 1979. Disponível em: http://compromissoeatitude.org.br/wp-content/uploads/2012/08/ SPM2006_CEDAW_portugues.pdf.

ORGANIZAÇÃ̄O DOS ESTADOS AMERICANOS. Carta da Organização dos Estados Americanos, 1967. Disponível em: http://www.oas.org/dil/port/tratados_A-41_Carta_da_Organiza\%C 3\%A7\%C3\%A3o_dos_Estados_Americanos.htm.

ORGANIZAÇÃO MUNDIAL DA SAÚDE. Estudio multipaís de la OMS sobre salud de la mujer y violencia doméstica contra la mujer, 2005. Disponível em: http:// www.compromissoeatitude.org.br/wp-content/uploads/2012/08/OMS_estudiomultipais_ resumendelinforme 1.pdf.

ORGANIZATION OF AMERICAN STATES (OAS). Inter-American Commission on Human Rights. Application filed with the Inter-American Court of Human Rights in the case of Campo Algodonero: Claudia Ivette González, Esmeralda Herrera Monreal and Laura Berenice Ramos Monárrez (Cases 12.496, 12.497 and 12.498) against the United Mexican States, 2007 [2005]. Disponível em: https://www.cidh.oas.org/demandas/12.496-78\%20Campo\%20Algodonero\%20Mexico\%204\%20noviembre\%202007\%20ENG.pdf.

ORGANIZATION OF AMERICAN STATES (OAS). Corte Interamericana de Direitos Humanos. Caso González y Otras ("Campo Algodonero") vs. México, 2009. Disponível em: http:// www.corteidh.or.cr/docs/casos/articulos/seriec_205_esp.pdf.

THE UNITED NATIONS. Universal Declaration of Human Rights, Art. 1, 1948. Disponível em: http:/ /www.un.org/en/udhrbook/pdf/udhr_booklet_en_web.pdf.

UNITED NATIONS WOMEN, US. Disponível em: http://www.unwomen.org/.

UNITED NATIONS. Convention on the Elimination of All Forms of Discrimination against Women. New York, 1979.

UNITED NATIONS. Convention on Political Rights of Women, New York, 1953. Disponível em: http://www.un.org.ua/images/Convention on the Political Rights of Women eng1.pdf.

UNITED NATIONS. Convention on Nationality of Married Women, 309 U.N.T.T.S. 65, entered into force Aug. 11, 1958. Disponível em: https://www.oas.org/dil/Convention_on_the_Nationality_ of_Married_Women_Bahamas.pdf.

[Received on $08 / 08 / 2018$

and accepted on 22/08/2018]

Direitos Humanos e a violência contra mulher: Caso Campo Algodonero

Resumo: O presente artigo busca analisar os direitos humanos com a lente do gênero. $E$ para isso volta ao passado com a finalidade explicar o desenvolvimento da sociedade de direitos e dos direitos das mulheres. A análise parte da premissa de que os direitos humanos são produtos sociais e que, portanto, vão refletir e representar os valores e interesses da sociedade que os produziu, neste caso, da sociedade capitalista. Um dos valores dessa sociedade é o patriarcado e a ideia da superioridade do homem enquanto ator social frente às mulheres. Esse valor está representado, então, nos direitos humanos que, no entanto, têm como uma das suas características a universalidade, a ideia que todos são sujeitos de tais direitos independente de qualquer identidade. Portanto a letra jurídica na qual os direitos humanos foram cunhados 
afirma uma igualdade que não existe na prática, já que mulheres são violentadas e têm seus direitos violados todos os dias, além da desigualdade de gênero presente em todo o mundo. Como forma de exemplificar e materializar tal realidade é apresentado um caso da Corte Interamericana de Direitos Humanos, o Caso Campo Algodonero, primeiro caso da Corte a citar a possibilidade de feminicídio e no qual se mostra a vulnerabilidade da vida e da integridade das mulheres.

Palavras-chave: Direitos Humanos; Direito das Mulheres; América Latina; feminicídio

Dandara Oliveira de Paula (dandara.o.depaula@gmail.com) is a M. A. student in Ethnic and Racial Relations. She holds a B. A. in International Relations from the Federal University of Rio de Janeiro (UFRJ) and has done specialization studies in Race, Racism and Human Rights at the Institute for Human Rights and Public Policies of UFRJ. Her research interests include gender, human rights, and national and international public policies of inclusion.

id 0000-0002-2374-9669 